\title{
On the Social Science Wars
}

\section{Citation}

Hochschild, Jennifer L. 2004. On the social science wars. Daedalus 133, no. 1: 91-94.

\section{Published Version}

http://dx.doi.org/10.1162/001152604772746747

\section{Permanent link}

http://nrs.harvard.edu/urn-3:HUL.InstRepos:3203708

\section{Terms of Use}

This article was downloaded from Harvard University's DASH repository, and is made available under the terms and conditions applicable to Other Posted Material, as set forth at http:// nrs.harvard.edu/urn-3:HUL.InstRepos:dash.current.terms-of-use\#LAA

\section{Share Your Story}

The Harvard community has made this article openly available.

Please share how this access benefits you. Submit a story.

\section{Accessibility}




\section{Jennifer Hochschild}

\author{
on the social \\ science wars
}

In the spring of 2003, as the founding editor of Perspectives on Politics, I helped to launch the first new journal sponsored by the American Political Science Association (APSA) in over a century. The new journal grew out of the general disaffection that had been floating around the discipline for years. In political science (as in other social sciences from economics to anthropology) a cold war has persisted for years between researchers who want to push the discipline in the direction of the 'real' sciences and

Jennifer Hochschild, a Fellow of the American Academy since 1996, is Henry LaBarre Jayne Professor of Government at Harvard University, with a joint appointment in the department of African and African American studies. She is the founding editor of "Perspectives on Politics." Her books include "The American Dream and the Public Schools" (with Nathan Scovronick, 2003), "Facing Up to the American Dream: Race, Class, and the Soul of the Nation" (1995), and "What's Fair: American Beliefs about Distributive Justice" (1981).

(C) 2004 by the American Academy of Arts \& Sciences those who want to maintain its roots in the humanities - and the new journal was, in part, meant to heal the rift.

APSA acknowledged dissatisfaction after analyzing a 1998 survey of its members and ex-members. Over two-fifths of the current members who responded, and half of the former members who responded, criticized the Association's flagship journal, the American Political Science Review (APSR); it headed the list of APSA activities with which respondents were unhappy. For example, individual respondents wrote that the APSR only "covers one small corner of the discipline," that it is "virtually useless for my teaching preparations and research specializations," and that it is not "reflective of the range of research methods and approaches in the discipline." The Association's report concluded that many political scientists saw the APSR as "too narrow, too specialized and methodological, and too removed from politics."

In short, some of the most prominent members of the discipline, as judged by their appearance in its most selective and prestigious journal, were developing a new type of 'science' that left other members of the discipline feeling angry, unimpressed, and disfranchised.

Several years later the Association's governing council approved the creation of a new journal and eventually selected me to serve as its first editor. The new journal's mission would be to publish "integrative essays" that are less specialized than normal research articles and that might "appl[y] ... political science to questions of public policy." The committee charged with implementing the council's directive added further mandates: the new journal should also include "state-of-the-discipline type essays, book reviews, reviews of literature 
in other disciplines with relevance to political science, conceptual and methodological essays, [and] a policy forum for debates on current policy issues, among other new materials" (italics added). Those other new materials might, for example, include "articles similar to those found in Science magazine." The implementing committee concluded, in something of an understatement, that Perspectives on Politics "should publish a very wide range of scholarship," that is, it should both widen the APSR's conception of the 'science' in 'political science' and restore 'politics' to it.

Although I was not involved in shaping the journal's mandate or design, I share its originators' goals. Like similar journals in other social science disciplines - for example, The Journal of Economic Perspectives and the new sociology journal Contexts - Perspectives on Politics is a response, in part, to a widespread perception that the drive to be scientific risks distorting our purposes, and that too many scholars are moving into narrower and narrower specializations, divorced from the concerns of nonspecialists and the 'real world.'

The respective merits of breadth and depth are a complicated and old issue. To some, specialization is an essential virtue in the face of a wide range of worthy topics and the deepening of knowledge about each; it is evidence of the maturation of the social sciences. Only by specializing does an individual have a chance to acquire sufficient substantive and methodological knowledge to develop sharp hypotheses, test them definitively against alternatives, and pinpoint their contribution to theoretical frameworks. Science consists in the cumulation of small advances built on previous small advances, all in the service of testing a larger theory - so that the whole becomes a good deal greater than the sum of its parts.

There is no intrinsic substantive content to this claim about scientific advancement; it can hold for the study of canonical political philosophers, for a particular area of the world, for explaining how a specific institution conducts its business, or for the revelation of hidden discrimination against disadvantaged groups or marginalized populations. It is also not intrinsically opposed to engagement with political or policy concerns; small bits of cumulative, specialized knowledge may be just as important for determining how to combat terrorism or reform tax law as for understanding the median voter theorem in legislative decision making.

Nevertheless, an alternative framework sees increased specialization as insufficient to, or even the downfall of, the social sciences. In this view, the compilation of small, cumulative findings is boring to read and teach, and narrows one's intellectual capacities. True science, defined now as real gains in knowledge and insight, consists in figuring out how to ask the right question even if it cannot be answered, understanding how people see the world from their own vantage point, and investigating large dynamics of change or stasis. Absent a broad vantage point, the ability to consider a problem from multiple perspectives, and the recognition of one's own inevitably partial and biased conceptual lenses, one cannot determine how and why the world works as it does. True science also entails knowing when to abandon a given framework rather than to continue trying to refine it but one cannot imagine alternative paradigms without breadth of vision.

Here also there is no intrinsic link between the call for integrative breadth and any particular topic of study, norma- 
tive stance, or degree of policy relevance. And in this framework too, the indeterminate signifier of 'science' or 'knowledge' is given a content intended to confer status on a particular set of practices.

Many political scientists do not aspire to the mantel of 'science,' however it is understood. They see their enterprise as closer to that of the humanities or history, in that they seek to give meaning to a phenomenon rather than to provide a causal explanation for it. But they too are involved in the methods wars that are roiling APSA and the social sciences.

Of course, there is no need to insist that the study of politics be either a science or an art, just as there is no logical reason to pit breadth against depth: these are separate rather than conflicting values. But every reader, writer, teacher, and journal editor must make trade-offs at the margins. Perspectives comes down on the side of integrative breadth rather than cumulative depth, but less from a deep commitment to the right way to conduct our business than from a perception of the need for a counterweight to most high-status academic journals.

As I pointed out earlier, all social sciences are facing this trade-off between breadth and depth in their publications, teaching, and graduate training. Most have begun a journal with a mission similar to Perspectives'; in fact, political science was a bit slow on the uptake, so we have been able to learn from the experiences of other disciplines. The underlying conflict over the changing and contested meaning of 'science' or 'knowledge' has, however, taken a different form in each of the four disciplines I know best.

The fact that the nastiest fights in political science are over methodological frameworks - not over competing political values or desirable hierarchies of power - might seem surprising for a dis- cipline that has at its core the analysis of the exercise of power. But political science encompasses the canon of political philosophy from Thucydides through Hannah Arendt, and also moves through qualitative research via case studies and historical or institutional analysis to highly technical quantitative analysis and formal reasoning. No other social science covers such a wide epistemological range so deeply; therefore it perhaps makes sense that we argue over how to do our work more than over what our work is about.

The discipline of sociology, in contrast, has largely avoided methods wars, but at the cost of arguably even more painful disputes. In recent years, battles among sociologists have revolved around the roles of race and gender in determining professional standing, and the presumed association of race and gender with differing understandings of science and knowledge. In the late 1990s, for example, the American Sociological Association (ASA) became embroiled in a bitter dispute over the editorship of the American Sociological Review. The nominations committee proposed an African American candidate and a slate of editorial board members who collectively emphasized qualitative and/or postmodernist research, sustained attention to issues of hierarchy and stratification, and a commitment to the view that the pursuit of scientific objectivity and precision was a mistaken, or at least too narrow, way to understand the social world. But the governing council of ASA chose a different set of candidates (one of whom was also African American), amid vehement accusations of racism against both specific named individuals and ASA as an organization. There have been similar battles over gender issues in ASA, incorporating the same underlying struggle over the mean- 
ing of science and the goals of social science analyses.

Economists are much less likely to debate methods for conducting research or to challenge the ascriptive characteristics of researchers; their central fight is over the legitimacy of critiques of neoclassical orthodoxy. Dissident Europeans have begun a movement for 'postautistic economics,' and in the United States a tiny tempest in a teapot at Harvard University was deemed significant enough to be reported in The Weekly Standard and The Economist. At Harvard a two-semester course of micro- and macroeconomics taught by a senior member of the department is the mandatory gateway course for all students who seek to do more study in economics. This course is, everyone agrees, totally conventional; that is its purpose. A chaired professor in the department proposed an alternative gateway course in microeconomics that would teach the same textbook but then explicitly analyze the assumptions underlying the neoclassical model; the department voted overwhelmingly not to permit it except as an elective. (Departmental faculty who were out of town took the almost unheard-of measure of voting by proxy, and the president of the university spoke on behalf of the extant course; this, despite a petition for the alternative course signed by hundreds of students and alumni.) It is hard to conceive of a sociology or political science department collectively deciding that all of its majors must take one particular twosemester course that is always taught in the same way before taking any other course in the discipline. In economics, in short, the meaning of 'science' is clear and widely shared; at issue is whether the mainstream can be overturned, rather than how broadly it is to be defined.
The discipline of anthropology has, like political science, engaged in disputes over methodology, but in this case the dominant position rejects the validity of positivism and conventional understandings of science. For several decades, the most prominent anthropologists have argued that scholars need to attend ever more to the subjectivity of the researcher, the power dynamics and subtle interplays of communication and emotion between subjects and researchers, the partiality of any claim to knowledge, and the context within which any research endeavor takes place. Good anthropological science, in this view, is a move away from the misguided search for objective truth, precisely defined and carefully tested causal hypotheses, and the cumulation of small findings; it is a move toward recognizing the inevitable role of the investigator's biases and flaws at the center of the research process. In anthropology, as in all disciplines, there is disagreement, but there the backlash against the hegemonic paradigm is swinging in the opposite direction from the concurrent backlash in political science.

In the end, I am reasonably optimistic about the foreseeable outcome of the social science wars, at least for political science. The APSR is becoming more eclectic in its assessment of what constitutes the best work, and other journals may follow its lead. Perspectives on Politics is opening channels for communication across subfields and rival frameworks. And the best graduate students and junior faculty are simply doing an end run around the boring old methods wars, by learning how to combine diverse epistemologies and modes of analysis in new and flexible ways - and that is good news for the future of my discipline. 